\title{
Daily pancreatic exocrine secretion and its relation with CCK, gastrin and secretin plasmatic levels in ruminant calves. Preliminary results
}

\author{
I Le Huërou-Luron 1, G Le Dréan 1, JA Chayvialle 2, V Romé 1, \\ C Bernard 2, R Toullec ${ }^{1}, \mathrm{P}$ Guilloteau ${ }^{1}$ \\ IINRA, Laboratoire du Jeune Ruminant, 35042 Rennes cedex ; 2INSERM, Hôpital \\ Edouard Herriot, 69374 Lyon cedex, France
}

\begin{abstract}
Knowledge of the mechanisms of synthesis and secretion of pancreatic enzymes in ruminants is poor compared to preruminants and mainly to monogastric animals, although understanding of these mechanisms may open ways to improve enzymatic degradation of food. The present experiment investigated the effects of meal on pancreatic exocrine secretion and on cholecystokinin (CCK), gastrin and secretin plasma levels of 60-120 d old ruminant calves. Four Holstein calves were fitted with two catheters into the pancreatic duct and in the duodenum, close to the pancreatic duct entry. The total pancreatic secretion was continuously collected and reintroduced into the intestine by means of a pump after constantly removing $7-8 \%$ of juice for analysis (96 samples per day and 3 kinetics per calf). Twenty other calves were fitted with a jugular vein catheter and blood was taken at $0.5 \mathrm{~h}$ before meal and at $0.5,1.0,1.5,2.0,3.0$, $4.0,5.0$ and $6.0 \mathrm{~h}$ after meal. All the animals were given once daily hay ad libitum and concentrate ad libitum up to a maximum of $3 \mathrm{~kg}$.
\end{abstract}

The pancreatic juice secretion $(13.4 \mathrm{ml} / \mathrm{kg} / \mathrm{d})$, which varied between animals (9.2 to 16.3 $\mathrm{ml} / \mathrm{kg} / \mathrm{d}$ ) agreed with the estimated values reported by Ternouth et al (1977, Br J Nutr, 37, 237-249) and McCormick and Stewart (1967, J Dairy Sci, 50, 568-571) in calves and Taylor (1962, Res Vet Sci, 3, 63-77) in sheep. The daily kinetic indicated a postfeeding change neither in the rate of juice and protein flows nor in the protein concentration of the juice. However, as in sheep, secretions appeared to be the greatest at night and the protein flow varied between animals (64 to $270 \mathrm{mg} / \mathrm{kg} / \mathrm{d}$ ). The lack of effect of the meal differed from the dramatic postprandial decrease of juice and protein secretions (down to 20 and $33 \%$ of the prefeeding values, respectively) and the large increase of protein concentration (up to $250 \%$ of the prefeeding value) we observed between 1 to 2 hours after meal in milk-fed calves (Le Huërou-Luron et al, 1994, Proc Soc Nutr Physiol, 3, 298). The mean plasma levels of secretin, gastrin and CCK which were 16, 76 and $99 \mathrm{pg} / \mathrm{ml}$ before feeding showed no variation after the meal ; in contrast, plasma secretin decreased while CCK and gastrin increased postprandially in preruminants (Touliec et al, 1992, Comp Biochem Physiol, 102A, 203-209).

Secretin and CCK are known to be involve in the regulation of the pancreatic juice flow and of the protein concentration, respectively. Furthermore, in ruminant calves, CCK $\mathrm{B} /$ gastrin receptor subtype which has similar affinities for CCK and gastrin, were more expressed than the CCK A subtype which has a much greater affinity for CCK than for gastrin (Guilloteau et al, 1994, Proc Soc Nutr Physiol, $3,289-290$ ), suggesting a regulatory role of gastrin on pancreatic function. Therefore, the postprandial constancy of pancreatic juice flow and protein concentration observed in ruminant calves during the present experiment, could be related to the similar trend recorded for plasma secretin, gastrin and CCK. That could be explained by the more regular stomach distension and flow rate of digesta than in preruminant calves. 